\begin{tabular}{|c|c|c|}
\hline$P$ & R & 7 \\
\hline
\end{tabular}

\title{
DZIEJE PAWLA I TEKLI
}

\author{
WSTĘP
}

Apokryficzne Dzieje Pawta stanowią jedne z pięciu wielkich dziejów apostolskich apokryficznych (Piotra, Pawła, Jana, Andrzeja i Tomasza), które powstały w II i III w. Dzieje Pawta powstały w drugiej połowie II w.: świadczy o nich Tertulian († ok. 220) i Orygenes (†254). Dzieje Pawta i Tekli stanowią najbardziej znaną część Dziejów Pawta. Nie wchodzimy tu w skomplikowany problem układu Dziejów Pawta i ich części: znajdzie je Czytelnik w przygotowywanym przez nas tomie II Apokryfów Nowego Testamentu.

Dzieje Pawła i Tekli rozsławiły postać męczennicy. W starożytności chrześcijańskiej pisali o niej: św. Atanazy (†373), św. Grzegorz z Nazjanzu († ok. 390), św. Grzegorz z Nyssy († ok. 394), św. Ambroży (†397), św. Jan Chryzostom $(\dagger 407)$, św. Hieronim (†419), św. Augustyn (430), by wyliczyć tylko kilku bardziej znanych. Na temat jej historyczności uczeni nie są zgodni, jedni uważają utwór za czystą fikcję, inni znajdują w nim elementy historyczne. Charakterystyczna jest tu postawa ks. Eugeniusza Dąbrowskiego, który pisze w związku z Dz 14,5n.: „Nie jest wykluczone, że jednym z powodów takiego rozwoju wydarzeń (zamieszek w Ikonium) było nawrócenie młodej mieszkanki Ikonium imieniem Tekla, co omawia obszerniej apokryf pt. 'Dzieje Pawła', napisany w latach 160 - 170 po Chr. przez anonimowego autora, właśnie z Antiochii Pizydyjskiej”. (Dzieje Apostolskie, Poznań 1961, 349).

Sam utwór pokazuje nam wierzenia ludowe w wieku II; niektóre nawet nas zaskakują, np. opis samoochrzczenia się przez Teklę czy naukę o dziewictwie, zbliżoną do herezji enkratyków. Z ciekawostek utworu zwróćmy uwagę na opis zewnętrznej postawy św. Pawła, który wywarł wpływ na ikonografię Apostoła.

Podajemy tu przekład utworu bez erudycyjnych not, chcąc uprzystępnić Czytelnikom ten nieznany w Polsce a ciekawy i warty przeczytania utwór z II w.*

* Zob. Acta Apostolorum Apocrypha, ed. R.A. Lipsius-M. Bonnet, 1, Lipsiae 1891 = Hildesheim 1972, $234-271$. 


\section{DZIEJE PAWŁA I TEKLI}

\section{Przybycie Pawła do Ikonium}

1. Gdy Paweł podążał do Ikonium po ucieczce z Antiochii, towarzyszyli mu w drodze Demas i kotlarz Hermogenes, pełni obłudy i schlebiali mu, jakoby go miłowali. Ale Paweł bacząc jedynie na dobroć Chrystusa nie uczynił im nic złego, lecz miłował ich tak bardzo, że starał się im uczynić miłymi wszystkie słowa Pańskie. (Jego naukę i wyjaśnienia Ewangelii) o narodzeniu i zmartwychwstaniu umiłowanego (Syna) oraz słowo po słowie objaśniał im wielkie czyny Chrystusa tak, jak On mu je objaśniał.

2. Pewien zaś mąż imieniem Onezyfor usłyszawszy, że Paweł przychodzi do Ikonium wyszedł mu na spotkanie wraz ze swymi dziećmi Simmią i Zenonem oraz z żoną Lektorą, aby go przyjąć. Opowiadał mu bowiem Tytus jak wygląda Pawel; nie widział go jednak, jak dotąd, cieleśnie, lecz jedynie w duchu.

3. Udał się więc drogą królewską ku Listrze i stanął oczekując go i przyglądając się przechodzącym, czy odpowiadają opisowi Tytusa. Ujrzał w końcu, że idzie Paweł: był on niskiego wzrostu, miał łysą głowę, krzywe nogi, był zdrowy i dobrze zbudowany, brwi mu się zbiegały, miał mały nos i był pełen wdzięku. Twarz jego przybierała raz wygląd ludzki, to znowu anielski.

4. Gdy Paweł ujrzał Onezyfora uśmiechnął się. Rzekł Onezyfor: „Witaj sługo Boga błogosławionego!” A on rzekł: „Łaska niech będzie z tobą i z domem twoim!" Jednak Demas i Hermogenes poczęli zazdrościć i jeszcze bardziej poruszyła się ich obłuda. Rzekł więc Demas: „Czyż i my nie jesteśmy sługami Błogosławionego? Czemu nas tak nie pozdrawiasz?". Rzekł Onezyfor: „Nie widzę w was owocu sprawiedliwości: jeśli jednej jest inaczej, nuże, chodźcie i wy i spocznijcie w moim domu!"

5. Gdy Paweł wszedł do domu Onezyfora, nastała w nim ogromna radość: (wszyscy) upadli na kolana, łamano chleb i głoszono naukę Bożą o wstrzemięźliwości i zmartwychwstaniu. A Paweł począł mówić:

Błogosławieni czystego serca, bowiem oni ujrzą Boga.

Błogosławieni, którzy strzegą czystym swe ciało, bo staną się świątynią Boga. Błogosławieni wstrzemięźliwi, bo do nich przemówi Bóg.

Błogosławieni, którzy wyrzekli się tego świata, bo będą się podobali Bogu.

Błogosławieni ci, którzy mają żony jakoby ich nie mieli, bo oni posiądą Boga w dziedzictwo.

Błogosławieni, którzy boją się Boga, bo oni staną się zwiastunami Boga.

6. Błogosławieni, którzy drżą wobec słów Boga, bo oni zostaną pocieszeni.

Błogosławieni, którzy przyjęli mądrość Jezusa Chrystusa, bo oni zostaną nazwani synami Najwyższego.

Błogosławieni, ci którzy strzegą chrztu, bo oni znajdują spoczynek u Ojca i Syna.

Błogosławieni, którzy osiągnęli poznanie Jezusa Chrystusa, bo oni pozostaną w świetle.

Błogosławieni, którzy z miłości Boga odeszli od kształtów tego świata, bo oni będą sądzili aniołów i będą błogosławieni po prawicy Ojca. 
Błogosławieni miłosierni, bo i oni doznają miłosierdzia, a gdy ujrzą dzień sądu nie będzie on dla nich gorzkim.

Błogosławione ciała dziewic, bo będą się Bogu podobały i nie stracą nagrody za swą czystość, bo Słowo Ojca stanie się dla nich sprawcą zbawienia w dniu jego Syna i osiągną odpoczynek na wieki wieków.

7. Gdy tak przemawiał Paweł po środku zgromadzenia, które miało miejsce w domu Onezyfora, pewna dziewica, Tekla, córka Theoklei zaręczona z mężem imieniem Thamyris, usiadłszy przy oknie domu słuchała dniem i nocą nauki o czystości głoszonej przez Pawła i nie odchodziła od okna, ale trwała w wierze przepełniona radością. A co więcej, gdy widziała liczne niewiasty i dziewice wchodzące do Pawła, zapragnęła i ona stać się godna tego, by stanąć przed obliczem Pawła i słuchać słowa o Chrystusie; nie widziała, jak dotąd, rysów jego twarzy, lecz słyszała jedynie jego głos.

\section{Thamyris i Tekla}

8. A gdy ona nie oddalała się od okna, posłała jej matka po Thamyrisa. On przybiegł rozradowany, jakoby miał ją już prowadzić do ślubu. Rzecze więc Thamyris do Theoklei: „Gdzie jest moja Tekla?” Rzekła Theoklea: „Muszę ci opowiedzieć nowe wydrzenie, Thamyrisie. Od trzech dni bowiem i trzech nocy Tekla nie wstaje od okna, aby jeść lub by pić, ale wpatruje się jakoby w najweselsze widowisko, tak bardzo bowiem zajmuje się obcym mężem, który uczy nauk ciekawych a barwnych, że nie mogę się nadziwić, jak wstyd dziewiczy może się tak naprzykrzać.

9. Thamyrysie, ten czlowiek poruszył miasto Ikonium, a także i twoją Teklę. Wszystkie bowiem kobiety i młode dziewczęta idą do niego dla pouczenia. On zaś mówi, że trzeba czcić jednego, jedynego Boga i żyć w czystości. Co więcej, moja córka tkwi jak pająk przyczepiona do okna, a jego słowa zawładnęły nią poprzez nowe pożądanie i dziwną namiętność. Dziewica zmieniła się w słuch na jego słowa i została przez niego usidlona. Lecz idź do niej, porozmawiaj z nią! Ty bowiem jesteś z nią zaręczony!"

10. Zbliżył się więc do niej Thamyris, bo kochał ją, a równocześnie lękał się z powodu tego stanu zachwycenia. I rzekł: „Teklo, która mi jesteś zaręczona, czemu tak siedzisz? Jakie cierpienie cię tak całkowicie ogarnęło? Wstydź się, zwróć się do swego Tamyrisa!” A nawet sama jej matka do niej mówiła: „Dziecko, czemu tak siedzisz wpatrzona w dół i odrętwiała nic nie odpowiadasz?" I zapłakali gorzko: Thamyris - bo stracił narzeczoną, Theoklea - dziecko, a służebnice - panią. Wielkie więc zapanowało zamieszanie w domu z żalu. A wśród tego wszystkiego jedynie nieporuszona trwała Tekla, wsłuchana w naukę Pawła.

11. Thamyris więc porwal się z miejsca, wybiegł na ulicę i przyglądal się wchodzącym i wychodzącym od Pawła. I ujrzal dwu mężów, którzy się bardzo bili. I rzekł do nich: „Mężowie, powiedzcie mi, kim jesteście i kim jest ten, który jest wewnątrz, a który wprowadza w błąd dusze młodzieńców i okłamuje dziewice tak, że nie chcą zawierać związków małżeńskich, lecz pozostają taki- 
mi, jakimi są. Obiecuję wam dać sutą zapłatę, jeśli mi przyniesiecie wiadomości o nim, należę bowiem do pierwszych tego miasta".

12. Na to Demas i Hermogenes mu odpowiedzieli: „Nie wiemy, kim jest on. Pozbawia on jednak młodzieńców narzeczonych, a dziewice oblubieńców nauczając, że zmartwychwstanie jest tylko dla tych, którzy żyją czysto i nie skazili ciała, lecz zachowali je czystym".

13. Thamyris rzekł do nich: „Nuże mężowie, chodźcie do mego domu i odpocznijcie u mnie!" Udali się więc na wielce kosztowną ucztę; było tam wiele wina, wielkie bogactwo, a stół był bogato zastawiony. Upoił ich Thamyris miłował bowiem Teklę i bardzo pragnął wziąć ją za żonę. W czasie uczty rzekł Thamyris: „Mężowie, powiedzcie mi, na czym polega jego nauka, abym i ja ją poznał, nie mało bowiem cierpię z powodu Tekli: ona bowiem tak pokochała obcego, że mogę zostać pozbawiony małżeństwa”.

14. Powiedzieli Demas i Hermogenes: „Zaprowadź go do prokonsula Kasteliosa jako zwodziciela tłumów nową nauką chrześcijańską. W ten sposób on zginie, ty natomiast otrzymasz Teklę za żonę. My natomiast ciebie pouczymy, że zmartwychwstanie, które głosi już się spełniło na naszych dzieciach i że zmartwychwstaniemy poznając Boga prawdziwego.

\section{Paweł i Tekla przed sądem}

Thamyris, gdy od nich usłyszał to wszystko powstał pełen zazdrości i napełniony szczerym gniewem i udał się do domu Onezyfora ze starszyzną, z urzędnikami i z licznym tłumem, uzbrojonymi w kije. I rzekł do Pawła: „Zdemoralizowałeś miasto Ikonium, a także moją narzeczoną tak, że mnie już nie chce: chodźmy do prokonsula Kasteliosa!” A cały lud wołał: „Wyrzucić czarownika, zdemoralizował nam wszystkie nasze żony!” I tak wzburzyły się tłumy.

16. Stanął więc Thamyris przed trybunałem i zawołał głosem wielkim: „Prokonsulu! Ten człowiek, o którym nie wiemy, skąd jest, nie pozwala dziewicom żenić się. Każ mu więc wobec ciebie wyjaśnić, dlaczego tak naucza!”. A Demas i Hermogenes odpowiedzieli do Thamyrisa: „powiedz, że jest chrześcijaninem i tak go zgubisz!" Ale prokonsul przeprowadził swoje zdanie, zawołał Pawła i rzekł do niego: „Kim jesteś i czego uczysz? Oskarżają cię o niemałe sprawy".

17. Paweł podniósł więc głos i zawołał: „Jeśli ja dziś jestem badany, czego nauczam, to posłuchaj, o prokonsulu! Bóg żywy, Bóg zemsty, Bóg zazdrosny, Bóg niczego nie potrzebujący a pragnący jednak zbawienia ludzi posłał mnie, abym wyrwał z zepsucia i nieczystości, a także od wszystkich rozkoszy i śmierci, aby już więcej nie błądzili. I dlatego też posłał Bóg swego Syna, którego ja zwiastuję ci i o którym pouczam, aby ludzie w nim pokładali swoją nadzieję, bo on jedynie lituje się nad błądzącym światem, aby ludzie nigdy nie otrzymali wyroku, lecz by mieli wiarę, lękali się Boga, poznali godność tego, co czcigodne i miłowali prawdę. Jeżeli więc nauczam tego, co mi od Boga zsotało objawione, cóż czynię złego, o prokonsulu?" Prokonsul usłyszawszy to, kazał 
związać Pawła i wrzucić do więzienia, aż w czasie sposobnym będzie mógł go dokładniej wysłuchać.

18. Tekla zaś w nocy zdjęła naramienniki i dała je odźwiernemu, a ten otworzył jej bramę, i udała się do więzienia; tam dała strażnikowi więziennemu srebrne zwierciadło, weszła do Pawła i usiadłszy u jego stóp słuchała, jak mówił o wielkich dziełach Bożych. Paweł zaś nie lękał się zupełnie, ale zachowywał się ze śmiałością Bożą; jej zaś wiara wzrastała, całowała jego więzy.

19. Gdy rodzina i Thamyris poszukiwali Tekli po drogach jakoby zagubionej, ktoś ze współniewolników odźwiernego doniósł, że ona wyszła nocą. Przyszli do odźwiernego, który im powiedział, że udała się do owego obcego, do więzienia. I weszli, jak im powiedzial, i znaleźli ją jakoby związaną miłością. Wyszli więc stamtąd, zgromadzili lud, i oznajmili o tym prokonsulowi.

20. On nakazał sprowadzić Pawła przed trybunał. Tekla natomiast pozostała zwinięta w kłębek na miejscu, na którym uczył Paweł siedząc w więzieniu. Ale prokonsul kazał i ją przyprowadzić przed trybunał. Ona przyszła ucieszona i pełna radości. Gdy więc znowu przyprowadzono Pawła, tłum tym głośniej zawołał: „To jest czarownik, zabij go!” Jednak namiestnik słuchał z przyjemnością Pawła, gdy on mówił o świętych czynach Chrystusa. Zwołał jednak radę, przywołał Teklę mówiąc: „Dlaczego nie chcesz wyjść za mąż za Thamyrisa wedle prawa, jakim rządzimy się w Ikonium?" Ona jednak stała wpatrzona w Pawła. Gdy więc ona nie odpowiadała, zawołała Theoklea, jej matka: „Spal bezwstydnicę, spal tę, co odrzuca narzeczonego, pośrodku teatru, aby odstraszyć wszystkie kobiety, które słuchały jego nauk!"

\section{Tekla na stosie. Ocalenie}

21. Prokonsul bardzo się tym przeląkł: Pawła ubiczowanego wygnał z miasta, Teklę natomiast skazał na spalenie. I natychmiast prokonsul powstawszy udał się do teatru, cały zaś tłum również poszedł na to widowisko tortur. A jak jagniątko na pustyni wygląda pasterza, tak Tekla szukała Pawła. I rozglądając się po tłumie ujrzała Pana, który siedział przybrawszy kształty Pawła i rzekła: „Przyszedł Paweł, aby mi się przyglądać, jakbym nie była zdolna znieść (cierpienia)". I zwróciła się wpatrzona weń, lecz on uleciał w niebo.

22. A chłopcy i dziewczęta znosili drzewo i słomę do spalenia Tekli. Gdy ją wprowadzono nagą namiestnik wybuchnął płaczem i podziwiał jej moc. Rozłożono drzewo i kaci nakazali jej, aby wstąpiła na stos. Gdy więc ona z rozłożonymi rękoma na kształt krzyża wstąpiła na drewna (stosu), podłużyli ogień, który choć rozbłysnął ogromny, nie dotknął jej jednak, bo Bóg zmiłowawszy się spowodowal, że rozległy się grzmoty podziemne, a w górze pojawiła się ciemna chmura pełna deszczu i gradu i wylała wszystko, co zawierała jej powłoka tak, że wielu znalazło się w niebezpieczeństwie, wielu zginęło. Ogień jednak został ugaszony, Tekla zaś została ocalona.

23. Paweł natomiast pościł wraz z Onezyforem, jego żoną i dziećmi w otwartym grobowcu przy drodze wiodącej z Ikonium do Dafne. Ponieważ minęło już wiele dni, jak oni pościli, rzekły dzieci do Pawła: „Jesteśmy głodne!” A nie miał za co zakupić chleba: Onezyfor bowiem opuścił wszystko to, co na- 
leżało do świata i poszedł za Pawłem wraz z całym domem. Wtedy Paweł zdjął z siebie wierzchnią szatę i rzekł: „Weź, dziecko, kup wiele chlebów i przynieś!” Gdy chłopiec kupował, ujrzał Teklę — była ona sąsiadką. Zdumiał się wielce i rzekł: „Teklo, gdzie idziesz?” Ona rzekła: „Szukam Pawła po ocaleniu od ognia”. A chłopiec rzekł: „Nuże, zaprowadzę cię do niego, trapi się bowiem z powodu ciebie, modli się i pości już od sześciu dni”.

24. Gdy doszła do grobowca (ujrzała) Pawła klęczącego i modlącego się tymi słowami: „Ojcze Chrystusa, niech Tekli nie dotknie ogień, ale bądź przy niej, bo ona jest Twoją!” A ona stojąc z tyłu zawołała: „Ojcze, który uczyniłeś niebo i ziemię, który jesteś Ojcem sługi twojego umiłowanego Jezusa Chrystusa, błogosławię Cię, że mnie ocaliłeś z ognia, abym ujrzała Pawła”. I powstał Paweł, ujrzał ją i zawołał: „O Boże, który znasz serca, Ojcze Pana naszego Jezusa Chrystusa, błogosławię Cię, bo to, o co prosiłem, szybko mi udzieliłeś i wysłuchałeś mnie".

25. W grobowcu zapanowała wielka miłość, bo wszyscy radowali się: Paweł, Onezyfor i wszyscy. Mieli pięć chlebów, warzywa i wodę i (sól) i radowali się z powodu świętych czynów Chrystusa. I rzekła Tekla do Pawła: „Obetnę sobie wokół włosy i pójdę z tobą dokądkolwiek pójdziesz". On na to rzekł: „Czasy są złe, ty natomiast jesteś piękna: oby cię nie dotknęła gorsza pokusa niż pierwsza, której byś nie mogła znieść i nie zlękła się". Rzekła mu Tekla: "Obyś tylko dał mi pieczęć Chrystusa (chrzest), a nie dotknie mnie pokusa". Rzekł Paweł: „Teklo, miej cierpliwość, a i ty także otrzymasz wodę (chrztu)”.

\section{Męczeństwo Tekli w Antiochii}

26. Odesłał Paweł Onezyfora z całą rodziną do Ikonium i tak wziąwszy ze sobą Teklę udał się do Antiochii. Skoro tylko oni weszli do miasta pewien Syryjczyk imieniem Aleksander, ujrzawszy Teklę, zakochał się w niej i błagał (o nią) Pawła prezentami i darami. Ale Paweł rzekł: „Nie znam tej niewiasty, o której mówisz, ani też nie jest ona moją". Ponieważ był on wielce możny i potężny, objął ją na środku ulicy. Ona jednak na to nie pozwalała, szukała Pawła. I zawołała głośno z goryczą: „Nie gwałć cudzoziemki, nie gwałć służebnicy Bożej. Należę do pierwszych w Ikonium, a zostałam wygnana z miasta, bo nie chciałam poślubić Thamyrisa". I chwyciwszy Aleksandra rozdarła mu płaszcz, strąciła mu wieniec z głowy i wystawiła go na pośmiewisko.

27. On zaś, choć ją kochał, ale pełen wstydu z powodu tego, co mu się wydarzyło, zaprowadził ją do prokonsula, a ten, gdy tylko Tekla potwierdziła, że to uczyniła, skazał ją na rzucenie dzikim zwierzętom. Na to kobiety, przerażone takim postępowaniem, poczęły krzyczeć przed trybunałem: „Zły wyrok, bezbożny wyrok!" Tekla jedynie prosiła sędziego, aby zostawili ją czystą, nim ją rzucą zwierzętom. A pewna kobieta (królowa) imieniem Tryfena, której umarła córka, wzięła ją w opiekę i była dlań pocieszeniem.

28. Ponieważ dzikie zwierzęta prowadzono w uroczystym pochodzie, przywiązano ją do groźnej lwicy, a królowa Tryfena jej towarzyszyła. Lwica zaś lizała stopy Tekli, która na niej siedziała, a tłumy szalały. Przyczyna jej skazania stała napisana: „Swiętokradztwo”. Kobiety i dzieci wołały z góry: 
„O Boże, bezbożny wyrok wydano w tym mieście”. A po uroczystym pochodzie znowu wzięła ją Tryfena, bowiem jej córka Falkonilla, która umarła, powiedziała jej we śnie: „Matko weź opuszczoną Teklę, cudzoziemkę na moje miejsce, aby się za mnie modliła, a wtedy zostanę przeniesiona do miejsca sprawiedliwych".

29. Gdy więc Tryfena przeprowadziła Teklę po pochodzie zwierząt, cierpiała, ponieważ miano nazajutrz rzucić Teklę zwierzętom i ponieważ pokochała ją bardzo, jak swoją córkę Falkonillę. Rzekła więc: „Druga córko moja, Teklo, nuże, pomódl się teraz za moje dziecko; tak mi ona bowiem objawiła we śnie”. A ta, bez zwłoki, zawołała głośno: „O Boże, mój Boże, Synu Najwyższego, który jesteś w niebiesiech: niech stanie się wedle jej woli: niech jej córka Falkonilla żyje na wieki!" Gdy to powiedziała Tekla, Tryfena odczuła ból na myśl, że taka piękność zostanie rzucona dzikim zwierzętom.

30. Gdy nadszedł ranek, przybył Aleksander, aby ją zabrać. On bowiem wydawał igrzyska - polowania na zwierzęta - i rzekł: „Namiestnik już zasiadł, tłum hałasuje z naszego powodu. Oddaj mi ją, abym ją zaprowadził na igrzyska dzikich zwierząt". A Tryfena krzyknęła tak głośno, że on uciekł. Wołała: „Żal za Falkonillą wdziera się po raz drugi do tego domu, a nie ma nikogo, kto by mi dopomógł! Ani dziecko — bowiem umarło, ani krewnych - jestem wdową. O Boże Tekli, mojego dziecka, wspieraj Teklę!"

31. I wysłał namiestnik żołnierzy, aby przyprowadzili Teklę. Ale Tryfena nie ustąpiła, ale wzięła ją za rękę i prowadziła mówiąc: „Córko moja Falkonillę zaprowadziłam do grobu, ciebie natomiast, Teklo, prowadzę na walkę z dzikimi zwierzętami!” I zapłakała gorzko Tekla i westchnęła do Pana, mówiąc: „Panie mój i Boże, któremu wierzę i do którego się uciekam, Ty, który wyrwałeś mnie z ognia, wynagródź Tryfenę, która współczuła Twojej służebnicy i obroniła moją niewinność!"

32. Powstal zgiełk: ryk zwierząt, krzyki ludu i kobiet tam siedzących. Ci krzyczeli: „Wprowadzić świętokradczynie!”, tamte natomiast: „Niech zginie miasto z powodu takiego bezprawia, zabij nas wszystkie, o prokonsulu, smutne to widowisko, zły to sąd!".

33. Wtedy wyrwano Teklę z rąk Tryfeny i zdarto szaty; włożyła przepaskę, rzucono ją na stadion i wypuszczono na nią lwy i niedźwiedzie. Przybiegła jednak dzika lwica i ułożyła się u jej stóp. Na to tłum kobiet zaczął głośno krzyczeć. Podbiegł ku niej niedźwiedź, ale wybiegła lwica rzuciła się na niego i rozerwała go. I znowu wybiegł lew Aleksandra poganiany przez ludzi, podbiegł ku niej, ale lwica zwarła się z nim w walce i rozszarpały się wzajemnie. Kobiety wybuchnęły ogromnym lamentem, bo zginęła lwica, która była jej obrończynią.

34. Rzucało się na nią jeszcze wiele zwierząt, a ona stała $\mathrm{z}$ wyciągniętymi rękoma i modliła się. A gdy skończyła modlitwę i ujrzała wielki dół pełen wody, rzekła: „Teraz nadszedł czas mojego obmycia”. I rzuciła się doń mówiąc: „W imię Jezusa Chrystusa chrzczę się w godzinie ostatecznej”. Gdy to ujrzały kobiety i cały tłum, wybuchnęli płaczem, wołając: „Nie rzucaj się do wody!" I nawet prokonsul zapłakał, że taką piękność pożrą foki. Ona jednak rzuciła się do wody w imię Jezusa Chrystusa, a foki ujrzały tylko światło bły- 
skawicy i wypłynęły martwe. Otaczała ją bowiem taka chmura ognia, że ani zwierzęta nie mogły się jej dotknąć, ani nie można było dojrzeć jej nagości.

35. Gdy wypuszczono inne jeszcze dzikie zwierzęta, kobiety zaczęły głośno krzyczeć i rzucały: jedne liście, inne nard, inne kasję, inne jeszcze cynamon a były to wszystko rzeczy wielce aromatyczne. A wszystkie zwierzęta, które wypuszczono poruszały się jakoby we śnie i nie ruszały jej. W końcu Aleksander powiedział prokonsulowi: „Mam bardzo dzikie byki, wypuśćmy je w czasie tych igrzysk!” Namiestnik pozwolił na to ze smutkiem mówiąc: „Rób, co chcesz!" A on kazał ją przywiązać do nogi pośrodku byków, a pod ich brzuchami poprowadził rozpalone łańcuchy, aby nimi bardzo podniecone rozszarpały ją. One więc skoczyły z miejsca, ale palący płomień spalił więzy, a ona stanęła jakoby nie związana.

36. A Tryfena, która stała przy wejściu na arenę, padła bez ducha, a służące jej wołały: „Królowa Tryfena umarła!” Wtedy prokonsul zakończył igrzyska, całe miasto zdjął lęk, a Aleksander padł do nóg prokonsula wołając: „Zmiłuj się nade mną i nad całym miastem i uwolnij rzuconą zwierzętom, aby nie zginęło całe miasto! Jeśliby bowiem usłyszał o tym cesarz, wkrótce zginęłoby miasto wraz z nami, bo królowa Tryfena była jego krewną, a ona umarła przy wejściu do teatru".

\section{Ocalenie Tekli}

37. I kazał przywołać namiestnik Teklę znajdującą się pośród zwierząt i rzekł do niej: „Kim ty jesteś? I jaką masz siłę w sobie, że żadne ze zwierząt nawet ciebie nie dotknie?” Ona na to rzekła: „Jestem służebnicą Boga żywego. A siła moja polega na tym, że uwierzyłam w Tego, którego uczynił Bóg chwalebnym — to jest w Jego Syna — dzięki Niemu to właśnie żadne ze zwierząt nawet mnie dotknęło. On bowiem, sam jeden, jest skałą zbawienia i podstawą życia bez śmierci. On jest miejscem ucieczki dla rozbitków, odpoczynkiem dla rozbitków, opieką dla ufających, i zgoła, jeśli kto w niego nie wierzy, nie będzie żył, lecz umrze na wieki”.

38. Gdy prokonsul usłyszał te słowa, kazał odnieść jej szaty i rzekł: „Włóż szaty!” Ona odpowiedziała: „Ten, który mnie nagą odział pomiędzy zwierzętami, ten sam odzieje mnie zbawieniem w dniu sądu". I wziąwszy szaty, odziała się w nie. I odesłał natychmiast namiestnik Teklę wypowiadając wyrok: „Uwalniam wam bogobojną służebnicę Boga, Teklę”. Wszystkie kobiety zawołały głosem wielkim i jakby jednymi ustami chwaliły Boga: „Jeden jest Bóg, który ocalił Teklę", a głos był tak potężny, że zatrzęsło się całe miasto.

39. Tryfena została powiadomiona o radosnym wydarzeniu, wyszła jej na przeciw z tłumem, objęła Teklę i rzekła: „Teraz wierzę, że martwi zmartwychwstaną, teraz wierzę, że dziecko moje żyje. Wejdź do wnętrza, zapiszę ci wszystko to, co mam". Tekla więc weszła do niej i pozostała w jej domu osiem dni, pouczając ją słowa Pańskiego tak, że uwierzyła większość służebnic. I zapanowała w domu wielka radość.

40. Ale Tekla pragnęła (widzieć) Pawła: wysyłała więc posłów na wszystkie strony i doniesiono jej, że przebywa w Mirze. Wzięła więc sługi i służebni- 
ce, przepasała się i pocięła ehiton na odzienie o kształcie męskim i udała się do Miry. I znalazła Pawła jak przepowiadał słowo Boże i stanęła przy nim. A on zdumiał się na jej widok i na widok tłumu, który był koło niej, zastanawiając się, czy ją nie dotknie znowu jakaś próba. Ona to spostrzegła i rzekła doń: „Wzięłam kąpiel, Pawle. Ten bowiem, który cię wspomagał w głoszeniu Ewangelii, Ten sam mnie wspomagał w (chrzcielnym) obmyciu się".

41. Paweł wziął ją za rękę i zaprowadził do domu Hermiasza i słuchał o wszystkim, co jej się przydarzyło i wielce się zdumiał, a ci, którzy słuchali, byli zbudowani i modlili się za Tryfenę. I powstała Tekla, i rzekła do Pawła: „Udam się do Ikonium!” A Paweł rzekł: „Idź i pouczaj słowa Bożego!” A Tryfena wysłała jej mnóstwo odzienia i złota tak, że mogła zostawić Pawłowi na pomoc dla ubogich.

\section{Powrót do Ikonium i śmierć}

32. Ona zaś udała się do Ikonium. I weszła do domu Onezyfora i padła na kolana na podłogę, gdzie siedząc słuchała, jak Paweł pouczał słów Bożych, i wybuchnęła płaczem, mówiąc: „O Boże mój i tego domu, gdzie zabłysło dla mnie światło, Chryste Jezu, Synu Boga, Ty, który byłeś moim wspomożeniem w więzieniu, wspomożycielem przed prokonsulem, wspomożycielem pośród ognia, wspomożycielem pośród zwierząt, Ty jesteś Bogiem, Tobie chwała na wieki, Amen".

43. I dowiedziała się, że Thamyris już umarł, żyła jednak jeszcze jej matka. Przywoławszy więc ową matkę, rzekła do niej: „Theokleo, matko, musisz uwierzyć, że żyje Pan na niebiosach. Jeśli pragniesz bogactw, da ci je Pan przeze mnie; jeśli chcesz swego dziecka, oto stoi przed tobą". To oświadczywszy udała się do Seleucji, gdzie wielu oświecała słowem Bożym, a potem usnęła pięknym snem.

44. Pewni obywatele miasta wyznający religię helleńską, a bądący lekarzami, wysłali do niej butnych młodzieńców, aby ją zgwałcili. Mówili: „Służy Artemidzie jako dziewica i dlatego ma moc uzdrawiania”. Za zrządzeniem jednak opatrzności Bożej weszła w skałę i żywa weszła pod ziemię. Udała się do Rzymu, aby ujrzeć Pawła, ale zastała go już śpiącego snem wiecznym. Pozostała tam niedługi czas i usnęła również pięknym snem i pochowano ją dwa lub trzy stadia od grobu Pawła, swego nauczyciela.

45. Została rzucona w ogień, gdy miała siedemnaście lat, dzikim zwierzętom - gdy miała osiemnaście, żyła w umartwieniu w jaskini, jak mówią, siedemdziesiąt dwa lata tak, że liczba jej lat wynosiła dziewięćdziesiąt. Dokonawszy niezliczonych uzdrowień spoczywa w miejscu świętych, usnąwszy 24 miesiąca września w Jezusie Chrystusie Panu naszym, któremu chwała i moc na wieki wieków. Amen. 